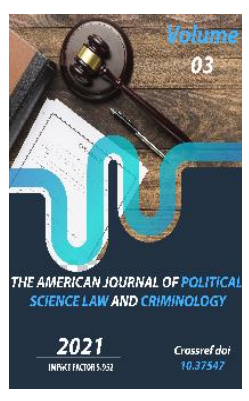

\title{
Problems And Prospects Of Green Legislation In The Republic Of Uzbekistan
}

Turdibekov Jamshid Qahramanovich

Student Of Private Law Faculty At Tashkent State University Of Law, Tashkent, Uzbekistan

Copyright: Original content from this work may be used under the terms of the creative commons attributes 4.0 licence.

\section{ABSTRACT}

In Uzbekistan, importance of legal environmentalism has been developing over the past 10 years. So, as a result, environmentalism on both industry and agriculture or individuals' daily life has become actual. For this purpose, it has also been adopted one of the most essential documents of the Republic of Uzbekistan, which is called a "The concept of environmental protection of the Republic of Uzbekistan until 2030" on a basis of 17 goals of sustainable development of the UN. Which means, until 2030 Uzbekistan will have developed eco protection system. This concept is one of the very example of ecological reformation that have conducted in Republic of Uzbekistan.

\section{KEYWORDS}

Green legislation, environmental issues, duties of citizens, Renewable Energy Sources, Law on PublicPrivate Partnerships, Environmental Code, Regulations for Connecting Businesses, National Green Tribunal (NGT), the Unified Electric Power System.

\section{INTRODUCTION}

The government of Uzbekistan is going ahead in a way of green politics in order to remain pristine landscape in Central Asia and find out more alternative means of utilizing of environment. In this way, environmental 
legislation of Republic of the Uzbekistan was built on these following crutial principles:

$>$ Comprehensible approach in all environmental issues;

$>$ Enhancing to control system over the utilization of natural recourses correctly;

$>$ Being legal on environmental legislation.

In addition, President of Uzbekistan, Shavkat Mirziyoyev, has told on stage of the United Nations in 72nd session on 22th September of 2017 " one of the most difficult issues in Central Asia is the problem of Aral sea. Drying of this huge sea can cause unpleasant outcomes. In fact, it has forced us to strive forward together. This is an only way to cope with". After, this speech, President and the government of Uzbekistan defected most of their attention to make Aral area more unspoiled enough to either gardening or farming. However, this environmental trouble of whole Central Asia is so taxing that seem to be unattainable since it will take more technology, more financial support, high knowledgeable scientists that ever before.

On the one hand, the importance of environmental legislation usually confront with problems related to rights of citizens. In other words, changing the environment in the devastating way unavoidably impact on the some rights based on land, adequate condition to live, in fact, the 1st principles of the 1972 Stockholm declaration highlighted that "people have fundamental right to freedom, equality and adequate conditions of life in an environment of a quality that permits a life of dignity and well-being, we bear a solemn responsibility to protect and improve the environment for present and future generations". In that, our duties, plans regarding our future environmentalism have been defined properly that never been before, moreover, it has also been marked create and apply more less damaging innovation in society provide population with sustainable environment, more importantly, being environmentally-friendly is growing, sustainable cooperation with other foreign countries such as: Japan, Norway, Germany in which already have more relevant experience.

So, human rights actually depend upon the environmental protections. In this way, there is strong connection between nature and individuals. In order to regulate and improve importance of legal environment, it has been adopted in main law. In other words, in constitutions What is more, today more than 130 countries incorporate environmental protections in their constitutions. Particularly, in constitution of the Republic of Uzbekistan, it is properly shown in chapter of "Duties of citizens" that "Citizens of Uzbekistan are obliged to treat the environment with care".The integration of environmental principles at a constitutional level recently is being so important that it might seem to play the link to change environment in a positive way, able to regulate legal system of green legislation in which is more the essential of the today's world. But it is not always enough.

Furthermore, the new era of renewable energy has affected our country. So, scientists have considered that finding an renewable energy is simple way to tackle ecological issues and key to the future, also, Uzbekistan has a great potential on using solar energy as there are almost 320 of a year is sunny. In addition, very beginning of the national anthem of Uzbekistan is this word "sunny". However, it is a real fact that Uzbekistan has no industrial scale solar power plants, as well as a wind 
potential in spite of those opportunities. Uzbekistan government therefore has been establishing legal framework for development of these energy. In this way, The Law on the Use of Renewable Energy Sources and the Law on Public-Private Partnerships have been adopted, as well as the Regulations for Connecting Businesses that Produce Electricity, Including from Renewable Energy Sources, to the Unified Electric Power System. Also, citizens are encouraged with some of the ways of taxing. However, that is only enough. Therefore, government of Uzbekistan should focus immensely on encouraging people to be more environmentally friendly and work on improving the innovations, which can help us to use renewable energy I suppose.

To enhance the green aspect of Uzbekistan's legislation, learning and protecting the precise experience of the world is essence I suppose. In doing so. For instance, one of the largest emerging economies in the world, India, has an experience of green trials (NGT) that the Supreme Court of India declared, "issues of environment must and shall receive the highest attention from this court". In doing so, Indian government has planned to be able to achieve expediency of justice, set the foundation for the emergence. National Green Tribunal (NGT) is specialized environmental tribunal in India, NGT exercises jurisdiction over matters involving substantial questions relating to environment. It may provide for certain reliefs, which inter alia include relief and compensation to the victims of pollution and other environmental damage; restitution of property damaged; and restitution of environment areas. Unlike a country Uzbekistan has no this kind of eco related courts. So, it will develop or allow to ease the process of court on environmental protection.
As Uzbekistan is considered the developing country of Asia, these kind of green trial would be one of the best options that have a positive influence on green aspect of Uzbekistan's politics and could regulate community in a way that to be more environmentally friendly.

From my perspective, importance of Environmental Code has also been increasing as far as environmental process is changing in a way that more complicated. It is becoming more and more important that legitimizing the field of ecology in today's rapid industrial growth, improving eco related laws in globalization. Thus, nowadays, many experts have been working on those issues. The main is that improving law enforcement practices in the field of economy and environmental protection as well. Since we will look at some countries, they have Environmental Code. For instance Estonia, Kazakhstan. They will help to regulate all issues like preservation of ecology or protection.

\section{CONCLUSION}

To conclude, it is clear that Uzbek nation has been appreciating at environment as precious gift of life. Nevertheless, in order to protect it, we ought to attract more attention on green legislation, which is an important factor of development of Uzbekistan. I can be pointed out that one of the priorities of the modern world, which is considered one of 17 goals of sustainable development of the UN, is climate action, plus life on land act. Uzbekistan has undoubtedly a vital role in that as a subject of the international public law and equal member of the UN. In this way, it has been showing that Uzbekistan is ready to support the green economy as well as invest money in sustainable solutions for these. Through this globally important project, we might be able to 
Doi: https://doi.org/10.37547/tajpslc/Volume03Issue03-16

recognize that we just need extremely strong operation that ever existed since these are kind of difficult problems that are impossible to solve lonely. We all need to give our potential to reshape the world into better ones.

\section{REFERENCES}

1. Stockholm declaration (1972);

2. "The concept of environmental protection of the Republic of Uzbekistan till 2030". 30.10.2019;

3. United Nations development progress "environmental justice, comparative experiences in legal empowerment", June.2014;

4. "Environmental law". Oxford university press. Stuart Bell and Donald McGillivray. 6th edition.2006;

5. World recourses institute report.2015;

6. Yuldashov, A. (2012). Government policies related to social protection of disabled persons in Uzbekistan: National and international aspects. Teise, 84, 186-191. https://doi.org/10.15388/Teise.2012.0.2

3;

7. Yakubova I. "Civil-law protection of honor, dignity and business reputation in the civil legislation of Uzbekistan and Japan" Review of law sciences, no. 3, 2018, pp. 79-85. doi:10.24412/2181-11482018-3-79-85;

8. Khujayev, S. A. (2018). Judgments under the law of the Republic of Uzbekistan «On banks and bank activity» in the new edition. International Journal of Legal Studies (IJOLS), 4(2), 295-301;

9. Mokhinur, B. (2020). A thorough review of the common law concept of" arbitrary termination" and" unfair dismissal" (including DIFC\&ADGM. Review of law sciences, (NOVEMBER);

10. Бобур Мукумов (2020). Оценка регулирующего воздействия нормативно-правовых актов на предпринимательскую деятельность в условиях пандемии коронавируса (на примере Торгово-промышленной палаты Республики Узбекистан). Review of law sciences, (2), 74-77. doi: 10.24412/2181-1148-2020-2-74-77.

\section{Websites:}

1. www.un.org

2. www.lex.uz 